American Journal of Applied Sciences 8 (10): 967-972, 2011

ISSN 1546-9239

(C) 2011 Science Publications

\title{
Comparison of Carbon and Selected Macronutrients in Forest-Floor Litter of Rehabilitated and Secondary Forests
}

\author{
${ }^{1}$ Melvin Ku Kin Kin, ${ }^{2}$ Japar Sidik Bujang, ${ }^{3}$ Osumanu Haruna Ahmed, \\ ${ }^{4}$ Nik Muhamad Ab. Majid, ${ }^{1}$ Roland Kueh Jui Heng and ${ }^{1}$ Silvester Jemat \\ ${ }^{1}$ Department of Forestry Science, Faculty of Agriculture and Food Sciences, \\ ${ }^{2}$ Department of Animal Science and Fishery, Faculty of Agriculture and Food Sciences, \\ ${ }^{3}$ Department of Crop Science, Faculty of Agriculture and Food Sciences, \\ University Putra Malaysia Bintulu Sarawak Campus, 97008 Bintulu, Sarawak, Malaysia \\ ${ }^{4}$ Department of Forest Management, Faculty of Forestry, \\ University Putra Malaysia, 43400 Serdang, Selangor, Malaysia
}

\begin{abstract}
Problem statement: Forest rehabilitation with human assistance by species selection and management shortens the time needed to rehabilitate degraded land as compared to natural succession. Empirical data on litter nutrient contents of tropical rain forests in Southeast Asia have been established, however it is limited to rehabilitated degraded lands. The objective of this study was to determine contents of carbon and selected macronutrients of nutrients present in the litter layer of different age stands and an adjacent secondary forest at Bintulu, Sarawak, Malaysia. Approach: Forest litter was sampled in $1 \mathrm{~m}^{2}$ quadrates of 5 points in research plots of $20 \times 20 \mathrm{~m}$ by carefully brushing off the standing litter layer on the forest floor followed by oven-drying and grinding before analysis using standard procedures for $\mathrm{pH}$, carbon, nitrogen, phosphorus, potassium, calcium and magnesium. Results: Results showed that litter layer was acidic, with $\mathrm{pH}$ ranging from 4.4-5.1 in water and 3.7-4.4 in $1 \mathrm{M} \mathrm{KCl}$. Carbon constituted the highest amount of element in litter, ranging from $285.6-363.9 \mathrm{~g} \mathrm{~kg}^{-1}$ followed by $\mathrm{N}$ with a range of 4.4-10.5 $\mathrm{g} \mathrm{kg}^{-1}$, followed by $\mathrm{P}$, ranging from $0.05-0.20 \mathrm{~g} \mathrm{~kg}^{-1}$. Content of $\mathrm{K}$ was in a range of 0.91-3.1 $\mathrm{g} \mathrm{kg}^{-1}$, while $\mathrm{Ca}$ and $\mathrm{Mg}$ contents were $0.3-7.9$ and $0.39-1.64 \mathrm{~g} \mathrm{~kg}^{-1}$ respectively. Litter layer mass and content of nutrients increased with stand age. Plots 1993, SF, 1999 and 1991 were clustered together while Plots 2002, 1996, 2005 and 2008 were in the other cluster. Stocks of nutrients in the plots were found to be in the order of $\mathrm{C}>\mathrm{N}>\mathrm{Ca}>\mathrm{K}>\mathrm{Mg}>\mathrm{P}$. Conclusion: The results are consistent with other secondary and primary forests in the tropics, suggesting that the project is successful in rehabilitating degraded forests in terms of restoring nutrient availability in forest litter.
\end{abstract}

Key words: Litter quality, macronutrients, secondary forest, rehabilitated forest

\section{INTRODUCTION}

Forest litter plays an important role in providing nutrients for plants in forest ecosystems. Comprising of leaves, twigs and other dead material, litter is a layer of dead plant material that may be present on the soil surface or that is not attached to a living plant (Reshi and Tyub, 2007). Quality of litter (physical and chemical nature and decomposability) produced in an ecosystem is controlled by species composition (BassiriRad, 2005).

Concentrations of nutrients, structural and defence compounds are displayed as litter quality where nutrient-rich leaves with less chemical and physical defences decompose faster than tough, nutrient-poor leaves (Swift et al., 1979; Lieth and Werger, 1989). Therefore, litter that are in stands with high nutrient-use efficiency are associated with low decomposition rates and at nutrient-poor sites, plants produce small amounts of low quality litter that decomposes slowly and intensify nutrient limitation (Swift et al., 1979; Vitousek, 1982; 1984).

Litter residing on the forest floor is a source and reservoir of nutrients (Sundarapandian and Swamy, 1999) and the rate of production and its decay regulates the energy flow, primary production and nutrient cycling to sustain a dynamic forest ecosystem and this is influenced by climatic and environmental conditions (Rajendraprasad et al., 2000).

Corresponding Author: Melvin Ku Kin Kin, Department of Forestry Science, Faculty of Agriculture and Food Sciences, University Putra Malaysia Bintulu Sarawak Campus, 97008 Bintulu, Sarawak, Malaysia Tel: +6086855722 Fax: +6086855416 
Am. J. Applied Sci., 8 (10): 967-972, 2011

Table 1: Stand structural characteristics of the study plots in Bintulu, Sarawak

\begin{tabular}{|c|c|c|c|c|c|}
\hline Plot & $\begin{array}{l}\text { Mean DBH } \\
(\mathrm{cm})\end{array}$ & $\begin{array}{l}\text { Basal Area } \\
\left(\mathrm{m}^{2} 0.04 \mathrm{~h}^{-1}\right)\end{array}$ & $\begin{array}{l}\text { Mean Height } \\
(\mathrm{m})\end{array}$ & $\begin{array}{l}\text { Stand } \\
\text { density }\end{array}$ & $\begin{array}{l}\text { Dominant } \\
\text { species }\end{array}$ \\
\hline $\begin{array}{l}2008 \\
\left(\mathrm{~N} 3^{\circ} 12.725^{\prime} \text { E } 113^{\circ} 03.770^{\prime}\right)\end{array}$ & $\begin{array}{l}0.76 \\
(0.04-2.61)\end{array}$ & 0.02 & $\begin{array}{l}0.46 \\
(0.01-1.40)\end{array}$ & 321 & $\begin{array}{l}\text { Sandoricum borneense Miq } \\
\text { Cotylelobium burckii Heim } \\
\text { Hopea aequalis } \text { P. S. Ashton }\end{array}$ \\
\hline $\begin{array}{l}2005 \\
\left(\mathrm{~N} 3^{\circ} 12.767^{\prime} \text { E } 113^{\circ} 04.474^{\prime}\right)\end{array}$ & $\begin{array}{l}2.08 \\
(0.45-5.83)\end{array}$ & 0.1 & $\begin{array}{l}2.54 \\
(0.53-7.19)\end{array}$ & 236 & $\begin{array}{l}\text { Shorea macrophylla (deVriese) P. S. Ashton } \\
\text { Elateriospermum tapos Blume } \\
\text { Sandoricum koetjape Merr. }\end{array}$ \\
\hline $\begin{array}{l}2002 \\
\left(\mathrm{~N} 3^{\circ} 12.745^{\prime} \text { E } 113^{\circ} 04.468^{\prime}\right)\end{array}$ & $\begin{array}{l}3.01 \\
(0.63-1.25)\end{array}$ & 0.23 & $\begin{array}{l}3.40 \\
(0.50-0.86)\end{array}$ & 238 & $\begin{array}{l}\text { Shorea macroptera Dyer } \\
\text { Palaquium gutta Burck } \\
\text { Shorea fallax Meijer }\end{array}$ \\
\hline $\begin{array}{l}1999 \\
\left(\mathrm{~N} 3^{\circ} 12.745^{\prime} \text { E } 113^{\circ} 04.468^{\prime}\right)\end{array}$ & $\begin{array}{l}6.00 \\
(0.82-15.50)\end{array}$ & 0.8 & $\begin{array}{l}6.15 \\
(1.49-10.73)\end{array}$ & 227 & $\begin{array}{l}\text { Dryobalanops beccarii Dyer } \\
\text { Shorea brunnescens } \mathrm{P} \text {. S. Ashton } \\
\text { Shorea ovata Dyer ex Brandis }\end{array}$ \\
\hline $\begin{array}{l}1996 \\
\left(\mathrm{~N} 3^{\circ} 12.728^{\prime} \text { E } 113^{\circ} 04.497^{\prime}\right)\end{array}$ & $\begin{array}{l}6.20 \\
(1.80-20.90)\end{array}$ & 0.4 & $\begin{array}{l}4.9 \\
(1.60-8.90)\end{array}$ & 102 & $\begin{array}{l}\text { Shorea ovata Dyer ex Brandis } \\
\text { Shorea macrophylla Dyer } \\
\text { Dryobalanops beccarii Dyer }\end{array}$ \\
\hline $\begin{array}{l}1993 \\
\left(\mathrm{~N} 3^{\circ} 12.768^{\prime} \text { E } 113^{\circ} 03.742^{\prime}\right)\end{array}$ & $\begin{array}{l}10.20 \\
(2.20-51.50)\end{array}$ & 1.85 & $\begin{array}{l}10.86 \\
(2.72-20.50)\end{array}$ & 156 & $\begin{array}{l}\text { Shorea dasyphylla Foxw. } \\
\text { Shorea ovata Dyer ex Brandis } \\
\text { Shorea mecistopteryx Ridl. }\end{array}$ \\
\hline $\begin{array}{l}1991 \\
\left(\mathrm{~N} 3^{\circ} 12.656^{\prime} \text { E } 113^{\circ} 03.604^{\prime}\right)\end{array}$ & $\begin{array}{l}8.16 \\
(1.31-35.10)\end{array}$ & 1.56 & $\begin{array}{l}9.30 \\
(2.00-20.50)\end{array}$ & 205 & $\begin{array}{l}\text { Shorea dasyphylla Foxw. } \\
\text { Shorea ovata Dyer ex Brandis } \\
\text { Durio zibethinus Rumph. ex Murray }\end{array}$ \\
\hline $\begin{array}{l}\text { SF } \\
\left(\mathrm{N} 3^{\circ} 12.848^{\prime} \text { E } 113^{\circ} 04.001^{\prime}\right)\end{array}$ & $\begin{array}{l}3.24 \\
(0.41-59.80)\end{array}$ & 1.64 & $\begin{array}{l}4.02 \\
(0.30-26.80)\end{array}$ & 546 & $\begin{array}{l}\text { Tejismanniodendron halophyllum (Baker) Kosterm. } \\
\text { Parishia maingayi Hook. f. } \\
\text { Allantospermum borneense Forman }\end{array}$ \\
\hline
\end{tabular}

Note: Values in parenthesis in the Plot column represents the GPS coordinates; values in parenthesis in Mean DBH and Mean Height columns represents the minimum and maximum values

Forest rehabilitation projects have been implemented around the world to combat the permanent irreversible damage caused by degradation of forest areas for human activities. In Malaysia, specifically at Bintulu, Sarawak, the Rehabilitation of Tropical Rainforest Ecosystems in 1991 has successfully converted abandoned slash and burn agriculture lands into forests by planting indigenous tree species (MiyaWaki, 1999). With forest rehabilitation demonstrated possible, further studies are needed to provide better understanding of the development of its ecosystem processes (Lieth and Lohmann, 1993). The objective of this study was to determine contents of carbon and selected macronutrients of nutrients present in the litter layer of different age stands and an adjacent secondary forest at Bintulu, Sarawak, Malaysia.

\section{MATERIALS AND METHODS}

Study Site: This study was conducted on a 47.5 ha site in the UPM-Mitsubishi Corporation forest rehabilitation project of different planting dates at Universiti Putra Malaysia Bintulu Campus, Sarawak, Malaysia. A phytosociological survey was carried out to determine the main and companion tree species of the area, followed by collection of seeds and growing them until fully-developed root system before randomly mixing and planting them akin to the system of natural forests according to MiyaWaki (1999) method. The stand is of a random mixed planted design with an initial planting density of 3 seedlings $\mathrm{m}^{-2}$. The soil series of this study site are of well-drained soils Nyalau and Bekenu (Ultisols) series. The soil is classified by the USDA-Soil Taxonomy Classification System as fine loamy, siliceous, isohyperthermic, red-yellow to yellow Tipik Tualemkuts.

The litter samples were taken from eight permanent plots of $20 \mathrm{~m} \times 20 \mathrm{~m}$ in Plot 2008 (3 years old), Plot 2005 (6 years old), Plot 2002 (9 years old), Plot 1999 (12 years old) and Plot 1996 (15 years old) in phase 4, Plot 1993 (18 years old) in phase 2 and Plot 1991 (20 years old) in phase 1 while a plot at an adjacent Secondary Forest (Plot SF). The characteristics of the study plots are described in Table 1.

Sample collection: Forest-floor litter was sampled from the 8 plots. Each sampling area of $1 \mathrm{~m}^{2}$ was brushed from the forest floor at 5 points of all plots, at four corners and at the middle of the plot. Care was taken in order not to sample soil along with the litter. Collections from five points were mixed into one sample for a $10 \mathrm{~m} \times 10 \mathrm{~m}$ and repeated for all four subplots of a $20 \mathrm{~m} \times 20 \mathrm{~m}$ plot. The litter samples were weighed and air-dried to a constant weight. Afterwards, the samples were ground to pass a $2 \mathrm{~mm}$ sieve for chemical analysis. 
Chemical analysis: Litter $\mathrm{pH}$ was determined using a glass electrode in solutions of ground litter in water to ratio of 1:5 and repeated for $1 \mathrm{M}$ potassium chloride with the same ratio to determine the true $\mathrm{pH}$, according to Tan (2005). Total Carbon (C) and Nitrogen (N) were determined by dry combustion method using LECO CHNS TruSpec 600 Analyser. The single dry ashing method followed by atomic absorption spectroscopy method was used to determine total Potassium (K), Calcium (Ca) and Magnesium (Mg). Total Phosphorus (P) content was determined using Bray 1 method by UV spectrophotometer after blue colour development.

Statistical Analysis: The contents of selected macronutrients of the studied plots were compared using Analysis of Variance (ANOVA, p <0.05) and means were compared using Duncan's multiple range test (DMRT), a post-hoc test if there was significant difference. Hierarchical cluster analysis was carried out to determine the grouping of plots.

\section{RESULTS}

The forest-floor litter $\mathrm{pH}$ for all plots ranged from 4.37 to 5.06 when measured in water and its true $\mathrm{pH}$, measured in $\mathrm{KCl}$ ranged between of 3.69-4.36 (Table 2). Across the litter $\mathrm{pH}$ in water and $\mathrm{KCl}$, significant differences were present.

Litter pH measured in water for plots 2008 and 1996 were significantly different in acidity compared to the remaining plots. Lower acidic values were obtained when measured in $\mathrm{KCl}$, but the ranking was similar to $\mathrm{pH}$ measured in water. Significant differences were seen in plots following ranking from highest to lowest in groups of 2005 and 1991, 2002 and SF, 2008 and 1996 while plots 1993 and 1999 were not significantly different between the groups.

Nutrient contents of the forest-floor litter varied among all plots and different nutrient types, showing significant differences among the plots. Litter $\mathrm{C}$ content ranged from 285.6 to $363.9 \mathrm{~g} \mathrm{~kg}^{-1}$ and were insignificantly different in all plots except Plot 2008, which had the lowest content of $\mathrm{C}$ (Table 3). The $\mathrm{N}$ content in the forest-floor litter of all plots studied ranged from 4.4 to $10.5 \mathrm{~g} \mathrm{~kg}^{-1}$, with the lowest being the youngest plot, Plot 2008 and highest in Plot SF (Table 3). The P content was the lowest among the 6 elements analysed, ranging from 0.05 to $0.20 \mathrm{~g} \mathrm{~kg}^{-1}$ with the lowest $\mathrm{P}$ contents at $0.05 \mathrm{~g} \mathrm{~kg}^{-1}$ in Plot 1996 and highest in Plot 1993, $0.20 \mathrm{~g} \mathrm{~kg}^{-1}$ (Table 3). The K content found in Plot 2008 was significantly highest among the studied plots with a range of 0.91 to $3.11 \mathrm{~g}$ $\mathrm{kg}^{-1}$. This was the opposite of the other elements analysed. The Ca content in the forest-floor litter ranged from 0.3 to $7.9 \mathrm{~g} \mathrm{~kg}^{-1}$, the highest was in Plot 1991 followed by Plots 1999, SF, 1993, 1996, 2002 and 2005 and 2008 being the lowest (Table 3). The Mg content in litter studied revealed a range of 0.39 to $1.64 \mathrm{~g} \mathrm{~kg}^{-1}$, and this was similar to $\mathrm{Ca}$ contents whereby the lowest values were found in plot 2008 and highest in 1999 and the other plots revealed no significant differences (Table 3).

The contents of $\mathrm{C}, \mathrm{N}, \mathrm{P}, \mathrm{K}, \mathrm{Ca}$ and $\mathrm{Mg}$ analysed by plots showed significant differences (Table 4). The C content in Plots 2008, 1993 and SF were highest and significantly different compared to the other elements analysed. Plots 1999 and 1991 had high C content, followed by $\mathrm{N}$ and $\mathrm{Ca}$ while $\mathrm{P}, \mathrm{K}$ and $\mathrm{Mg}$ were not significant. Plots 2002 and 1996 recorded high C content followed by N. Plot 2005 had a distinctively high $\mathrm{C}$ content followed by $\mathrm{N}$ while $\mathrm{P}, \mathrm{K}, \mathrm{Ca}$ and $\mathrm{Mg}$ was not significantly different (Table 4).

\begin{tabular}{lll}
\multicolumn{4}{l}{ Table 2: Litter layer $\mathrm{pH}$ of the study sites in Bintulu, Sarawak } \\
\hline Plot & $\mathrm{pH}$ (water) & $\mathrm{pH}(1 \mathrm{M} \mathrm{KCl})$ \\
\hline 2008 & $4.365 \pm 0.04^{\mathrm{d}}$ & $3.688 \pm 0.05^{\mathrm{c}}$ \\
2005 & $5.058 \pm 0.08^{\mathrm{a}}$ & $4.363 \pm 0.03^{\mathrm{a}}$ \\
2002 & $4.728 \pm 0.07^{\mathrm{bc}}$ & $4.060 \pm 0.04^{\mathrm{b}}$ \\
1999 & $4.618 \pm 0.04^{\mathrm{bc}}$ & $3.895 \pm 0.03^{\mathrm{bc}}$ \\
1996 & $4.425 \pm 0.11^{\mathrm{d}}$ & $3.715 \pm 0.09^{\mathrm{c}}$ \\
1993 & $4.863 \pm 0.13^{\mathrm{abc}}$ & $4.143 \pm 0.19^{\mathrm{ab}}$ \\
1991 & $4.945 \pm 0.09^{\mathrm{ab}}$ & $4.353 \pm 0.12^{\mathrm{a}}$ \\
SF & $4.780 \pm 0.05^{\mathrm{bc}}$ & $4.063 \pm 0.09^{\mathrm{b}}$ \\
\hline
\end{tabular}

Note: Means within column having similar letters are not significantly differently using Duncan Multiple Range Test (DMRT)

Table 3: Contents of C, N, P, K, Ca and Mg of forest-floor litter indifferent plots

\begin{tabular}{lllllll}
\multicolumn{2}{l}{ Table 3: Contents of C, N, P, K, Ca and Mg of forest-floor litter indifferent plots } \\
Plot & $\begin{array}{l}\mathrm{C} * \\
\left(\mathrm{~g} \mathrm{~kg}^{-1}\right)\end{array}$ & $\begin{array}{l}\mathrm{N} * \\
\left(\mathrm{~g} \mathrm{~kg}^{-1}\right)\end{array}$ & $\begin{array}{l}\mathrm{P} * \\
\left(\mathrm{~g} \mathrm{~kg}^{-1}\right)\end{array}$ & $\begin{array}{l}\mathrm{K} * * \\
\left(\mathrm{~g} \mathrm{~kg}^{-1}\right)\end{array}$ & $\begin{array}{l}\mathrm{Ca}^{* *} \\
\left(\mathrm{~g} \mathrm{~kg}^{-1}\right)\end{array}$ & $\begin{array}{l}\mathrm{Mg} * \\
\left(\mathrm{~g} \mathrm{~kg}^{-1}\right)\end{array}$ \\
\hline 2008 & $285.61 \pm 10.34^{\mathrm{b}}$ & $4.36 \pm 0.30^{\mathrm{e}}$ & $0.166 \pm 0.02^{\mathrm{ab}}$ & $3.106 \pm 0.42^{\mathrm{a}}$ & $0.312 \pm 0.09^{\mathrm{c}}$ & $0.389 \pm 0.04^{\mathrm{c}}$ \\
2005 & $341.31 \pm 4.02^{\mathrm{a}}$ & $8.09 \pm 0.31^{\mathrm{bc}}$ & $0.137 \pm 0.03^{\mathrm{b}}$ & $1.328 \pm 0.18^{\mathrm{b}}$ & $2.017 \pm 0.42^{\mathrm{bc}}$ & $0.873 \pm 0.08^{\mathrm{bc}}$ \\
2002 & $340.35 \pm 3.51^{\mathrm{a}}$ & $6.53 \pm 0.32^{\mathrm{cd}}$ & $0.147 \pm 0.01^{\mathrm{ab}}$ & $1.388 \pm 0.38^{\mathrm{b}}$ & $3.150 \pm 0.17^{\mathrm{b}}$ & $1.025 \pm 0.04^{\mathrm{b}}$ \\
1999 & $363.91 \pm 2.89^{\mathrm{a}}$ & $8.91 \pm 1.45^{\mathrm{ab}}$ & $0.126 \pm 0.02^{\mathrm{b}}$ & $1.284 \pm 0.17^{\mathrm{b}}$ & $6.685 \pm 0.57^{\mathrm{a}}$ & $1.640 \pm 0.20^{\mathrm{a}}$ \\
1996 & $349.77 \pm 3.07^{\mathrm{a}}$ & $5.85 \pm 0.20^{\mathrm{de}}$ & $0.050 \pm 0.01^{\mathrm{c}}$ & $1.061 \pm 0.14^{\mathrm{b}}$ & $3.193 \pm 0.96^{\mathrm{b}}$ & $0.915 \pm 0.18^{\mathrm{bc}}$ \\
1993 & $363.02 \pm 6.22^{\mathrm{a}}$ & $8.58 \pm 1.29^{\mathrm{abc}}$ & $0.202 \pm 0.03^{\mathrm{a}}$ & $0.907 \pm 0.12^{\mathrm{b}}$ & $3.782 \pm 0.60^{\mathrm{b}}$ & $1.334 \pm 0.35^{\mathrm{ab}}$ \\
1991 & $339.75 \pm 5.27^{\mathrm{a}}$ & $8.13 \pm 0.09^{\mathrm{bc}}$ & $0.108 \pm 0.01^{\mathrm{bc}}$ & $1.073 \pm 0.03^{\mathrm{b}}$ & $7.923 \pm 0.99^{\mathrm{a}}$ & $1.240 \pm 0.17^{\mathrm{ab}}$ \\
SF & $343.99 \pm 14.93^{\mathrm{a}}$ & $10.50 \pm 0.21^{\mathrm{a}}$ & $0.124 \pm 0.01^{\mathrm{b}}$ & $1.535 \pm 0.20^{\mathrm{b}}$ & $3.263 \pm 0.29^{\mathrm{b}}$ & $1.410 \pm 0.58^{\mathrm{ab}}$ \\
\hline
\end{tabular}

Note: $* \mathrm{p}<0.05 ; * *: \mathrm{p}<0.01$, Means within column having similar letters are not significantly different by Duncan Multiple Range Test (DMRT) 
Am. J. Applied Sci., 8 (10): 967-972, 2011

Table 4: Comparison of C, N, P, K, Ca and Mg content in forest-floor litter between rehabilitated forest and an adjacent secondary forest

\begin{tabular}{|c|c|c|c|c|c|c|c|c|}
\hline \multirow[b]{2}{*}{ Element } & \multicolumn{8}{|l|}{ Plots } \\
\hline & 2008 & 2005 & 2002 & 1999 & 1996 & 1993 & 1991 & SF \\
\hline$\overline{\mathrm{C}\left(\mathrm{g} \mathrm{kg}^{-1}\right)}$ & $285.61 \pm 10.34^{\mathrm{a}}$ & $341.31 \pm 4.02^{\mathrm{a}}$ & $340.35 \pm 3.51^{\mathrm{a}}$ & $363.91 \pm 2.89^{\mathrm{a}}$ & $349.77 \pm 3.07^{\mathrm{a}}$ & $363.02 \pm 6.22^{\mathrm{a}}$ & $339.75 \pm 5.27^{\mathrm{a}}$ & $343.99 \pm 14.93^{\mathrm{a}}$ \\
\hline $\mathrm{N}\left(\mathrm{g} \mathrm{kg}^{-1}\right)$ & $4.36 \pm 0.30^{\mathrm{b}}$ & $8.09 \pm 0.31^{\mathrm{b}}$ & $6.53 \pm 0.32^{\mathrm{b}}$ & $8.91 \pm 1.45^{\mathrm{b}}$ & $5.85 \pm 0.20^{\mathrm{b}}$ & $8.58 \pm 1.29^{b}$ & $8.13 \pm 0.09^{b}$ & $10.50 \pm 0.21^{\mathrm{b}}$ \\
\hline $\mathrm{P}\left(\mathrm{g} \mathrm{kg}^{-1}\right)$ & $0.166 \pm 0.02^{\mathrm{b}}$ & $0.137 \pm 0.03^{\mathrm{c}}$ & $0.147 \pm 0.01^{c}$ & $0.126 \pm 0.02^{\mathrm{c}}$ & $0.050 \pm 0.01^{\mathrm{c}}$ & $0.202 \pm 0.03^{\mathrm{b}}$ & $0.108 \pm 0.01^{\mathrm{c}}$ & $0.124 \pm 0.01^{\mathrm{b}}$ \\
\hline $\mathrm{K}\left(\mathrm{g} \mathrm{kg}^{-1}\right)$ & $3.106 \pm 0.42^{\mathrm{b}}$ & $1.328 \pm 0.18^{\mathrm{c}}$ & $1.388 \pm 0.38^{\mathrm{c}}$ & $1.284 \pm 0.17^{\mathrm{c}}$ & $1.061 \pm 0.14^{\mathrm{c}}$ & $0.907 \pm 0.12^{\mathrm{b}}$ & $1.073 \pm 0.03^{\mathrm{c}}$ & $1.535 \pm 0.20^{\mathrm{b}}$ \\
\hline $\mathrm{Ca}\left(\mathrm{g} \mathrm{kg}^{-1}\right)$ & $0.312 \pm 0.09^{\mathrm{b}}$ & $2.017 \pm 0.42^{\mathrm{c}}$ & $3.150 \pm 0.17^{\mathrm{bc}}$ & $6.685 \pm 0.57^{b}$ & $3.193 \pm 0.96^{\mathrm{bc}}$ & $3.782 \pm 0.60^{\mathrm{b}}$ & $7.923 \pm 0.99^{\mathrm{b}}$ & $3.263 \pm 0.29^{\mathrm{b}}$ \\
\hline $\operatorname{Mg}\left(\mathrm{g} \mathrm{kg}^{-1}\right)$ & $0.389 \pm 0.04^{\mathrm{b}}$ & $0.873 \pm 0.08^{\mathrm{c}}$ & $1.025 \pm 0.04^{\mathrm{c}}$ & $1.640 \pm 0.20^{\mathrm{c}}$ & $0.915 \pm 0.18^{\mathrm{c}}$ & $1.334 \pm 0.35^{\mathrm{b}}$ & $1.240 \pm 0.17^{\mathrm{c}}$ & $1.410 \pm 0.58^{\mathrm{b}}$ \\
\hline
\end{tabular}

Note: Means within column having similar letters are not significantly different by Duncan Multiple Range Test (DMRT)

Table 5: Comparison of litter-layer mass and nutrient contents in ecosystems in the tropics

\begin{tabular}{lllllllll}
\hline & Age & $\begin{array}{l}\text { Litter } \\
\text { Ecosystem/Location }\end{array}$ & $\begin{array}{l}\left.\mathrm{N} \mathrm{t}^{-1}\right) \\
(\%)\end{array}$ & $\begin{array}{l}\mathrm{P} \\
\left(\mathrm{g} \mathrm{kg}^{-1}\right)\end{array}$ & $\begin{array}{l}\mathrm{K} \\
\left(\mathrm{g} \mathrm{kg}^{-1}\right)\end{array}$ & $\begin{array}{l}\mathrm{Ca} \\
\left(\mathrm{g} \mathrm{kg}^{-1}\right)\end{array}$ & $\begin{array}{l}\mathrm{Mg} \\
\left(\mathrm{g} \mathrm{kg}^{-1}\right)\end{array}$ & References \\
\hline Primary forest, Manaus, Brazil & - & 6.50 & 1.50 & 0.28 & 1.08 & 1.62 & 1.14 & Luizao (1995) \\
Primary forest, Maracá, Brazil & - & 7.70 & 1.00 & 0.34 & 5.40 & 4.70 & 1.80 & Villela (1995) \\
Dipterocarp forest, Sarawak & - & 5.90 & 0.95 & 0.10 & 4.50 & 1.50 & 1.10 & Sutton et al. (1983) \\
Secondary forest, Manaus, Brazil & 5 & 5.25 & 1.09 & 0.30 & 2.90 & 6.40 & 1.30 & Mckerrow (1992) \\
Secondary forest, Manaus, Brazil & 10 & 6.32 & 1.10 & 0.10 & 1.06 & 5.94 & 1.39 & Tapia-Coral et al. (2005) \\
Secondary forest, Jenaro Herrera, Peru & 16 & 13.50 & 1.44 & 0.48 & 1.36 & 4.98 & 1.36 & Tapia-Coral \\
Secondary forest, Bintulu, Malaysia & 22 & 7.45 & 1.05 & 0.17 & 1.54 & 3.26 & 1.41 & This study \\
Rehabilitated (1991), Bintulu, Malaysia & 20 & 18.26 & 0.81 & 0.11 & 1.07 & 7.92 & 1.24 & This study \\
Rehabilitated (1993), Bintulu, Malaysia & 18 & 11.29 & 0.86 & 0.20 & 0.91 & 3.78 & 1.33 & This study \\
Rehabilitated (1996), Bintulu, Malaysia & 15 & 5.84 & 0.59 & 0.05 & 1.06 & 3.19 & 0.92 & This study \\
Rehabilitated (1999), Bintulu, Malaysia & 12 & 6.18 & 0.89 & 0.13 & 1.28 & 6.69 & 1.64 & This study \\
Rehabilitated (2002), Bintulu, Malaysia & 9 & 5.93 & 0.65 & 0.15 & 1.39 & 3.15 & 1.03 & This study \\
Rehabilitated (2005), Bintulu, Malaysia & 6 & 5.25 & 0.81 & 0.14 & 1.33 & 2.02 & 0.87 & This study \\
Rehabilitated (2008), Bintulu, Malaysia & 3 & 4.52 & 0.44 & 0.12 & 3.11 & 0.31 & 0.39 & This study \\
\hline
\end{tabular}

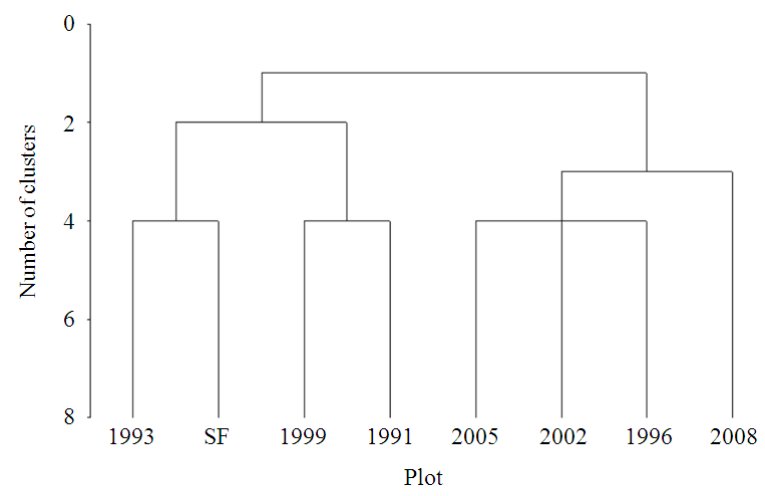

Fig. 1: Cluster analysis of studied sites based on nutrient content in forest-floor litter (Source: Tapia-Coral et al., 2005)

Clustering in Fig. 1 showed that the contents of $\mathrm{C}$ and other macronutrients of older plots were more similar to the secondary forest plot than the younger plots. Plot 1993 was most similar to Plot SF followed by Plot 1991 and Plot 1999 being clustered together. The other distinct group was Plot 2005, 2002 and 1996 grouped together followed by Plot 2008 (Fig. 1).

\section{DISCUSSION}

The lower acidity of plots 2008 and 1996 may be attributed to the lack of standing litter as compared to the matured plots (Akbar et al., 2010). The mix of species planted in the plots affects the $\mathrm{pH}$ and in turn affects the availability of nutrients when decomposed down and leached into the soil (Facelli and Pickett, 1991). The C sequestration increases with stand age while recently established stands have low nutrient contents (except for $\mathrm{K}$ ) possibly as a result of previous planting site preparation and soil nutrient availability factors.

Low content of $\mathrm{N}$ causes stunted growth of all plant organs (Barker and Pilbeam, 2006) and overall causes slow growth of trees in all plots as compared to $\mathrm{SF}$. The absence of $\mathrm{N}$-fixing legume trees in the plots and nutrient translocation before senescence aggravates the $\mathrm{N}$ content in the litter. The results from all plots studied showed low $\mathrm{N}$ content compared with other secondary and primary forests in Table 5.

The different species of trees in the plots attributed to the varying $\mathrm{P}$ contents and the related availability of nutrients may influence the uptake and release patterns of P (BassiriRad, 2005). Content of P studied in other forest types in Table 5 showed that rehabilitated forests ranged within the lower values

Mineral leaching from the litter layer into the soil is common for $\mathrm{K}$ and is heightened during wet seasons (Luizao and Schubart, 1987). This observation was consistent with other findings (Luizao, 1995; Villela, 1995; Sutton et al., 1983; Mckerrow, 1992), with 
exceptions for the very high and low value of plot 1991 and 2008 respectively (Table 5).

Plot SF recorded high Mg content compared to the secondary forests studied in previous work (Luizao, 1995; Villela, 1995; Sutton et al., 1983; Mckerrow, 1992) and the varying ages of the rehabilitated forests showing a trend of attaining secondary forest like when age increases (Table 5). Nutrients stored in forest litter are vital for forests as its ecosystems are of closed nutrient cycling. Macronutrient content was found highest in the older plots as well as the naturally regenerating forest plot followed by the younger plots. C stocks were the highest in all plots, followed by N, $\mathrm{Ca}, \mathrm{K}, \mathrm{Mg}$ and $\mathrm{P}(\mathrm{C}>\mathrm{N}>\mathrm{Ca}>\mathrm{K}>\mathrm{Mg}>\mathrm{P})$.

The more established plots were capable of stocking more $\mathrm{C}$ over time, as woody and leaf mass are more and fully developed. The opposite was observed in $\mathrm{K}$ content where plot 2008 was significantly higher than the group of other plots.

\section{CONCLUSION}

The contents of carbon and macronutrients in litter in the forest rehabilitation project plots were found to be comparable to other secondary forests and primary forests in the tropics. Comparison of litter quality characteristics by stand age indicated that the plots are recovering, achieving secondary forests' status as rehabilitated forest stand age increases. The ecological aspect of litter was attested to have rehabilitated lands and thus the overall objective of the project.

\section{ACKNOWLEDGEMENT}

The researchers would like to extend their appreciation to the management and field staff of Universiti Putra Malaysia Bintulu Sarawak Campus for their assistance. This study was supported by the grant from Mitsubishi Corporation, Japan and fellowship grant (GRF) of Universiti Putra Malaysia.

\section{REFERENCES}

Akbar, M.H., O.H. Ahmed, A.S. Jamaluddin, N.M.N.A. Majid and H. Abdul-Hamid et al., 2010. Differences in soil physical and chemical properties of rehabilitated and secondary forests. Am. J. Applied Sci., 7: 1200-1209. DOI: 10.3844/ajassp.2010.1200.1209

Barker, A.V. and D.J. Pilbeam, 2006. Handbook of Plant Nutrition. 1st Edn., CRC Press, ISBN: 0824759044, pp: 632.
BassiriRad, H., 2005. Nutrient Acquisition by Plants: An Ecological Perspective. 1st Edn., SpringerVerlag, Berlin, ISBN: 3540241868, pp: 347.

Facelli, J.M. and S.T.A. Pickett, 1991. Plant litter: Its dynamics and effects on plant community structure. Botanical Rev., 57: 1-32. DOI: 10.1007/BF02858763

Lieth, H. and M. Lohmann, 1993. Restoration of Tropical Forest Ecosystems. 1st Edn., Springer, ISBN: 0792319451, pp: 272.

Lieth, H. and M.J.A. Werger, 1989. Tropical Rain Forest Ecosystems: Biogeographical and Ecological Studies. 1st Edn., Elsevier Scientific Publ. Co., Amsterdam, ISBN: 0444427554, pp: 713.

Luizao, F.J. and H.O.R. Schubart, 1987. Litter production and decomposition in a terra-firme forest of Central Amazonia. Experientia, 43: 259265. DOI: $10.1007 / \mathrm{BF} 01945549$

Luizao, F.J., 1995. Ecological studies in contrasting forest types in Central Amazonia. PhD Thesis. University of Stirling, Stirling, UK, pp: 288. Mckerrow, A.J., 1992. Nutrient stocks in abandoned pastures of the central Amazon basin prior to and following cutting and burning. MSc Thesis, University of North Carolina, Raleigh, USA., pp: 116.

MiyaWaki, A., 1999. Creative ecology: Restoration of native forests by native trees. Plant Biotechnol., 16: 15-25. http://www.wdc-

Rajendraprasad, M., P.N. Krishnan and P. Pushpangadan, 2000. Vegetational characterisation and litter dynamics of the sacred groves of Kerala, Southwest India. J. Tropical Forest Sci., 12: 320335.

Reshi, Z. and S. Tyub, 2007. Detritus and Decomposition in Ecosystems. 1st Edn., New India Publishing Agency, New Delhi, ISBN: 8189422154, pp: 269.

Sundarapandian, S.M. and P.S. Swamy, 1999. Litter production and leaf-litter decomposition of selected tree species in tropical forests at Kodayar in the Western Ghats, India. Forest Ecol. Manage., 123: 231-244. DOI: 10.1016/S0378-1127(99)00062-6

Sutton, L.S., T.C. Whitmore and A.C. Chadwick, 1983. Tropical Rain Forest: Ecology and Management. 1st Edn., Blackwell Scientific Publications, Oxford, ISBN: 0632011424, pp: 498.

Swift, M.J., O.W. Heal and J.M. Anderson, 1979. Decomposition in Terrestrial Ecosystems. 1st Edn., University of California Press, Oxford, ISBN: 0520040015, pp: 372. 
Tan, K. H., 2005. Soil Sampling Preparation and Analysis. 2nd Edn., Taylor and Francis, New York, ISBN: 0849334993, pp: 623.

Tapia-Coral, S.C., F.J. Luizao, E. Wandelli and E.C.M. Fernandes, 2005. Carbon and nutrient stocks in the litter layer of agroforestry systems in central Amazonia, Brazil. Agroforestry Syst., 65: 33-42. DOI: $10.1007 / \mathrm{s} 10457-004-5152-0$

Vitousek, P.M., 1982. Nutrient cycling and nutrient use efficiency. Am. Naturalist, 119: 553-572.
Villela, D.M., 1995. Nutrient Cycling in a Monodominant and other Rain Forest Types on Maraca Island, Brazil. PhD Thesis, University of Stirling, Stirling, UK. pp: 180.

Vitousek, P.M., 1984. Litterfall, nutrient cycling and nutrient limitation in tropical forests. Ecology, 65: 285-298. DOI: 10.2307/1939481 